Supplement of Atmos. Chem. Phys., 18, 4519-4531, 2018

https://doi.org/10.5194/acp-18-4519-2018-supplement

(C) Author(s) 2018. This work is distributed under

the Creative Commons Attribution 4.0 License.

(c) (1)

Supplement of

Nucleation of nitric acid hydrates in polar stratospheric clouds by meteoric material

\author{
Alexander D. James et al. \\ Correspondence to: Benjamin J. Murray (b.j.murray@leeds.ac.uk) and John M. C. Plane (j.m.c.plane@ leeds.ac.uk)
}

The copyright of individual parts of the supplement might differ from the CC BY 4.0 License. 


\section{XRD of $\mathrm{SiO}_{2}$}

X-Ray Diffraction (XRD) patterns of the two $\mathrm{SiO}_{2}$ materials are shown in Figure $\mathrm{S} 1$. No crystalline phases were detected.

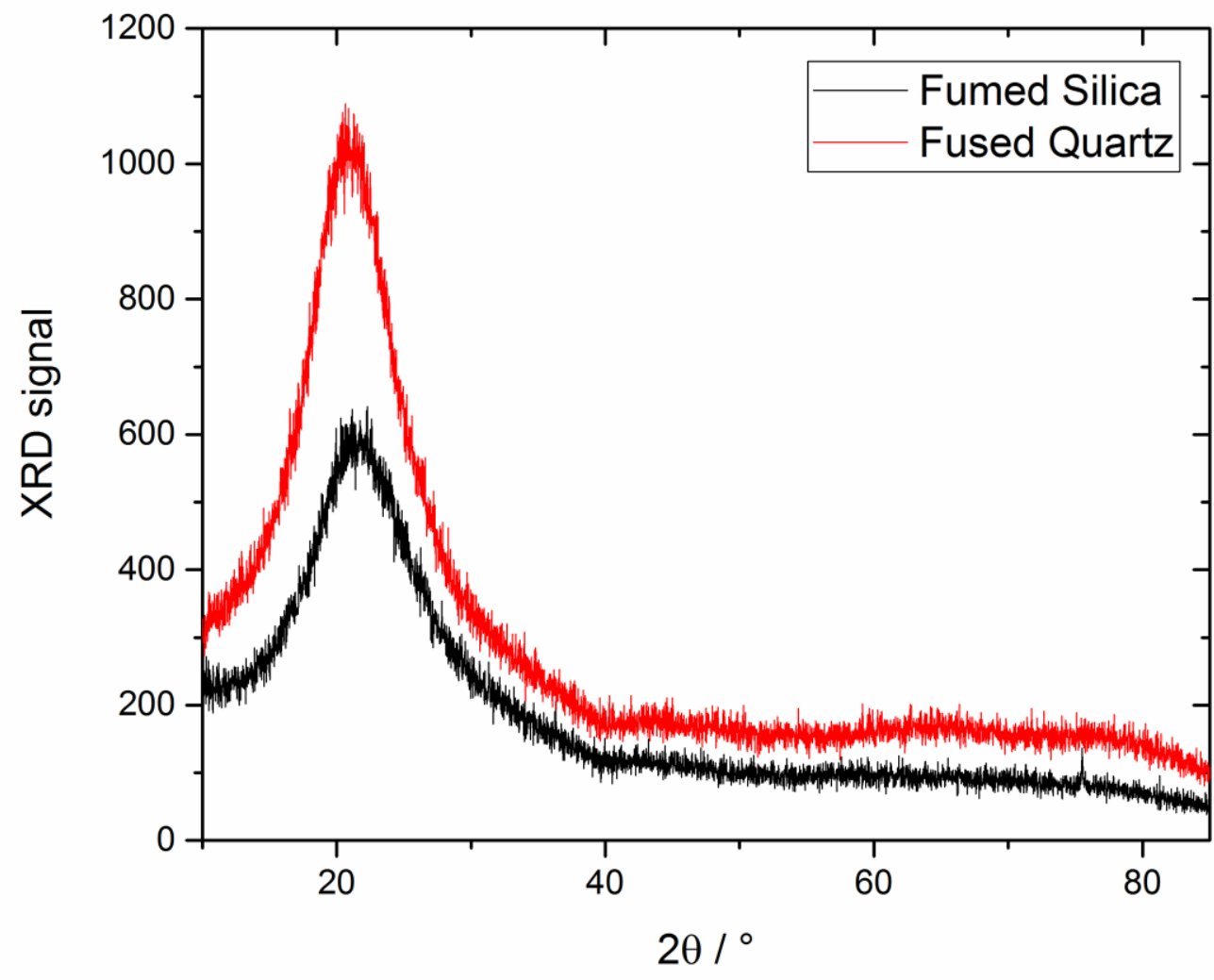

Figure S1: Powder X-Ray Diffraction (XRD) of $\mathrm{SiO}_{2}$ materials. Diffraction patterns for the two $\mathrm{SiO}_{2}$ materials, showing broad peaks from the amorphous materials, but no sharp peaks from crystalline phases.

\section{Electron Microscopy of $\mathrm{SiO}_{2}$}

Fused quartz and fumed silica were both imaged in a Scanning Electron Microscope (FEG-SEM - FEI Nova 450) and the elemental composition of the fused quartz examined with Energy Dispersive X-ray spectroscopy (EDX, AMTEK at $18 \mathrm{kV}$ ). Figure $\mathrm{S} 2$ shows $\mathrm{SEM}$ images of the two $\mathrm{SiO}_{2}$ materials. 


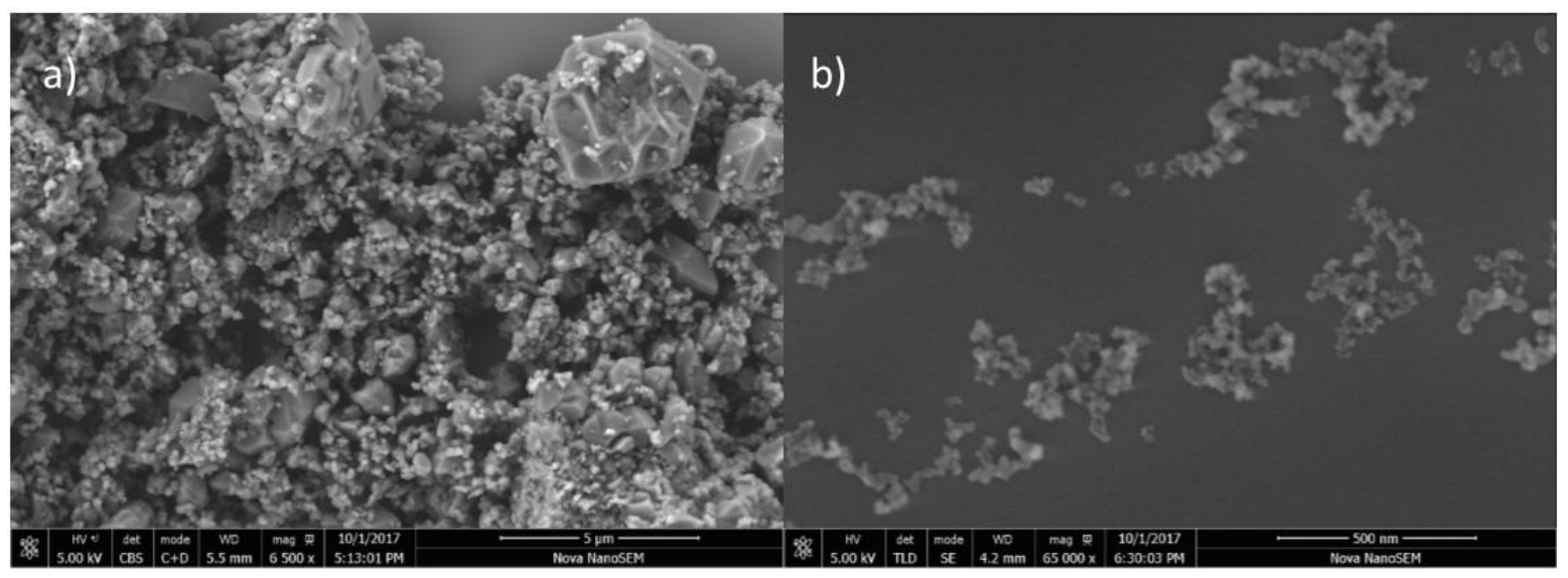

Figure S2: SEM images of a) fused quartz and b) fumed silica.

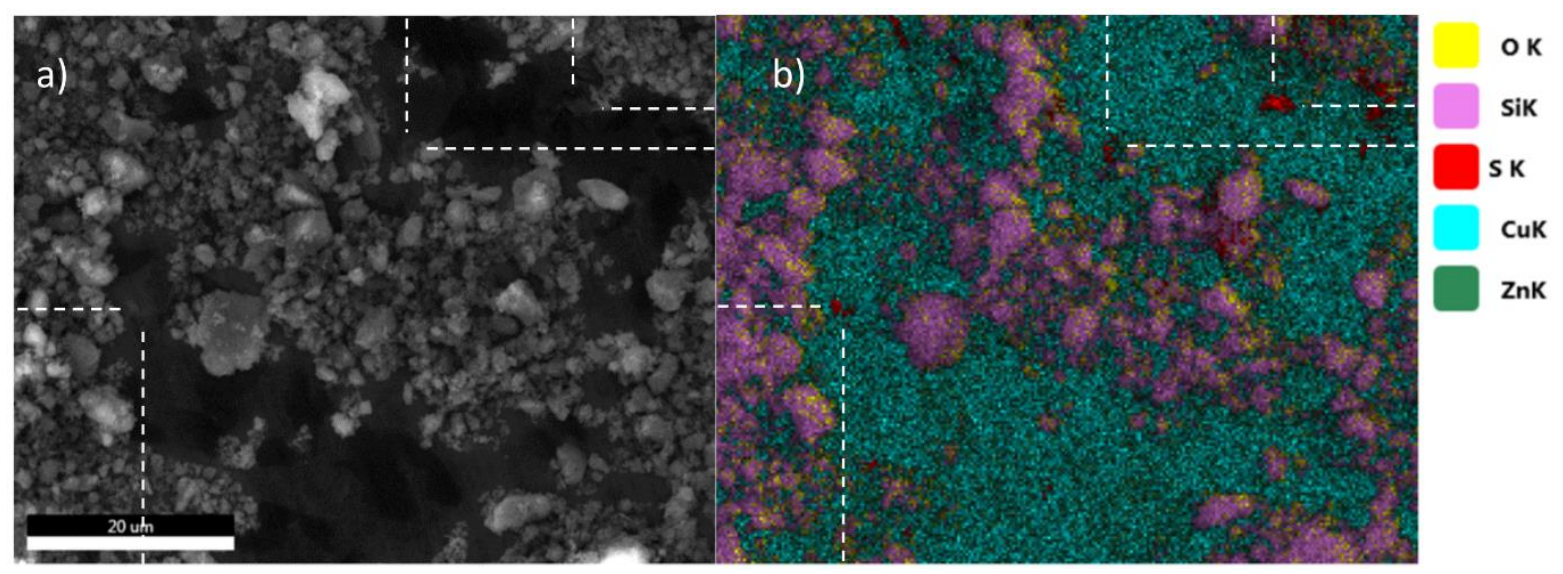

Figure S3: a) SEM image and b) EDX map of fused quartz. Dashed white lines indicate the position of EDX $S$ signals on the SEM image. $S$ is associated with the $\mathrm{Cu} / \mathrm{Zn}$ substrate ( $\mathrm{S}$ is also found on the bare substrate) rather than the fused quartz particles.

SEM shows that the fumed silica is indeed chain agglomerates similar in morphology to MSPs. This is in good agreement with previous work (Bogdan et al., 2003).

SEM shows that the fused quartz has a broad size distribution, with particles ranging from hundreds of $n m$ to several $\mu \mathrm{m}$ in diameter. EDX detected no elements other than $\mathrm{Si}$ and $\mathrm{O}$ in these particles. Since the limit of detection here is on the order of $0.1 \%$ this does not conclusively rule out contamination as a source of nucleation by the fused quartz material, however this is rarely practically possible.

\section{Model Description}

The Whole Atmosphere Community Climate Model (WACCM) is a 3D numerical high-top coupled chemistry-climate model extending vertically from the surface to about $140 \mathrm{~km}$ (Marsh et al., 2013), which is part of the NCAR Community Earth System model (CESM) (Hurrell et al., 2013). In this study, CESM v1.2.2 and WACCM 4 (CAM v5.3.57) were used. Aerosol properties are computed using CARMA (Community Aerosol and Radiation Model for Atmospheres) (Toon et al., 
1988;Toon et al., 1979;Turco et al., 1979), which employs a sectional (size bin) representation. Specified dynamics (SD) was used, with meteorological values nudged below $50 \mathrm{~km}$ using the Modern-Era Retrospective Analysis for Research and Applications (MERRA) reanalysis for an initial spin up period followed by conditions from July 2010 to July 2014 (Rienecker et al., 2011).

WACCM includes a detailed neutral chemistry for the middle atmosphere based on the Model for Ozone and Related Chemical Tracers (MOZART) (Kinnison et al., 2007) and sulfur chemistry(English et al., 2011); there are 66 species, including the sulfur-containing species $\mathrm{OCS}, \mathrm{S}, \mathrm{SO}, \mathrm{SO}_{2}, \mathrm{SO}_{3}, \mathrm{HSO}_{3}, \mathrm{H}_{2} \mathrm{SO}_{4}$, and a large set of photolysis, gas phase, and heterogeneous reactions (Lamarque et al., 2012). Emissions of $\mathrm{SO}_{2}, \mathrm{NO}_{2}, \mathrm{NO}, \mathrm{CO}, \mathrm{NO}$, and $\mathrm{DMS}$, and boundary conditions including for OCS were included (Lamarque et al., 2012). $\mathrm{SO}_{2}$ emissions from both continuously and explosively erupting volcanos were also included(Mills et al., 2016). $\mathrm{H}_{2} \mathrm{SO}_{4}$ visible photolysis rates (Feierabend et al., 2006), including the pressure dependence (Miller et al., 2007), and Lyman a rates were also included(Lane and Kjaergaard, 2008). The aerosol surface area densities required to calculate the rates of heterogeneous reactions are obtained from CARMA. All simulations were performed on a $2.5^{\circ} \times 1.9^{\circ}$ longitude/latitude grid with 88 model levels up to $\sim 140$ $\mathrm{km}$, and CAM4 physics.

The CARMA aerosols here include two "groups": pure sulfate and mixed sulfate, where mixed sulfate consists of sulfate with an MSP core. Both groups have 28 bins between $0.34 \mathrm{~nm}$ and $1.6 \mu \mathrm{m}$, with particle densities of 2.0 and $1.9 \mathrm{~g} \mathrm{~cm}^{-3}$ for pure sulfate and mixed sulfate, respectively. Pure sulfate is formed in the smallest size bin by homogeneous nucleation of $\mathrm{H}_{2} \mathrm{SO}_{4}$ and $\mathrm{H}_{2} \mathrm{O}$. MSPs are input into the smallest size bin of the mixed sulfate group (so that they begin as $100 \%$ MSP core), between 75 and $110 \mathrm{~km}$ (Kalashnikova et al., 2000), with the input scaled to a selected global input rate from meteoric ablation (Carrillo-Sánchez et al., 2016).

Condensation and evaporation of $\mathrm{H}_{2} \mathrm{SO}_{4}$ occurs for both aerosol groups, but evaporation from mixed sulfate only occurs for particles that have a core fraction less than 0.5. For mixed sulfate, this condensation and limited evaporation mimics the reaction between $\mathrm{H}_{2} \mathrm{SO}_{4}$ and MSP metal atoms (Saunders et al., 2012). Coagulation occurs within and between both aerosol groups (English et al., 2012).

Output mass concentrations of cores (MSPs) for the $70 \mathrm{hpa}$ level sampled at $67^{\circ} \mathrm{N}$ (where Polar Stratospheric Clouds (PSCs) have been observed (Voigt et al., 2005)) is shown in Figure S4. The mean of February across these four years is used in the main body of the paper as an estimate of the available MSP mass. 


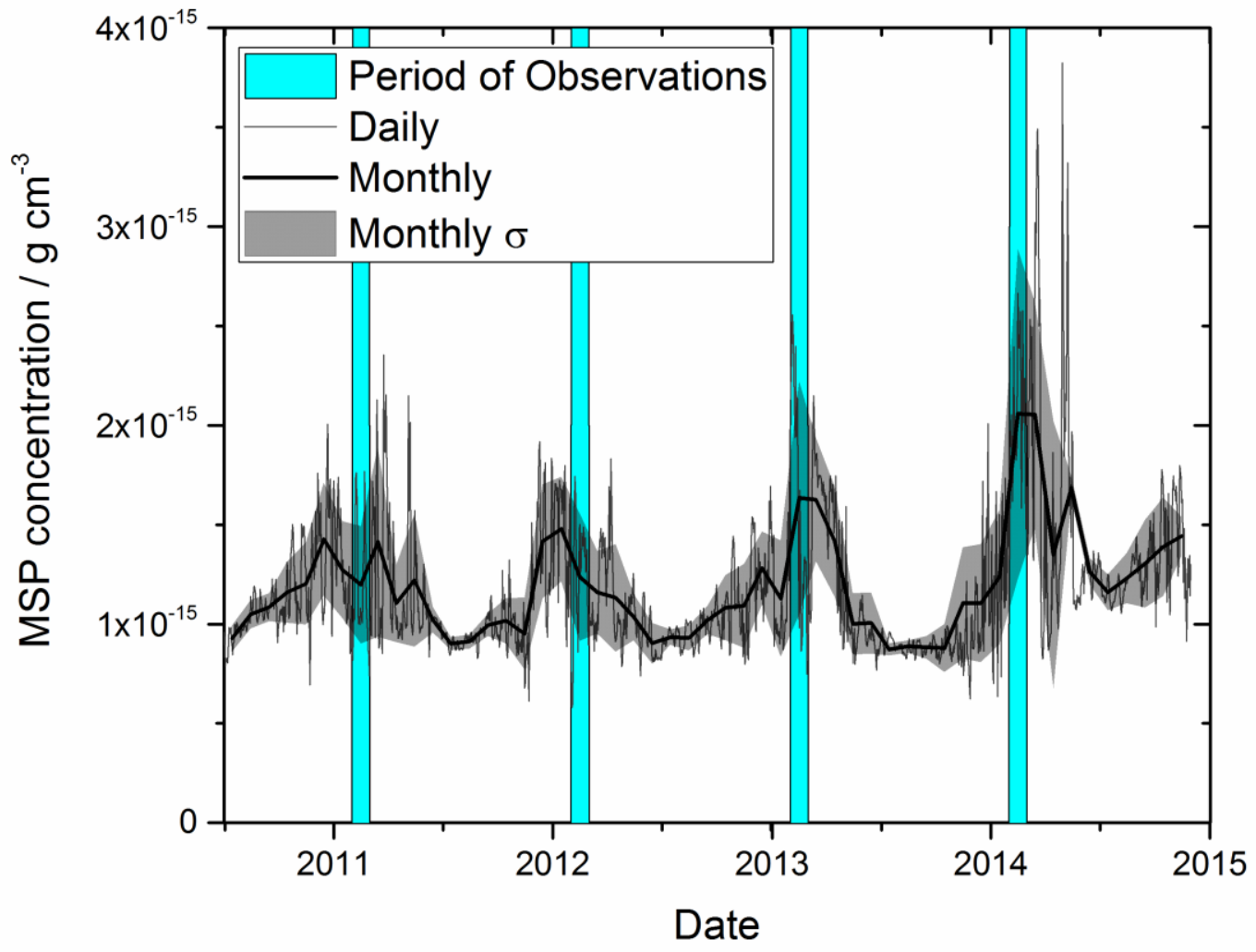

Figure S4: MSP mass concentrations from WACCM-CARMA. Zonally averaged data is shown for $67^{\circ} \mathrm{N}$ and $70 \mathrm{hPa}$. The thin grey line shows daily data, thick black line monthly means, and the grey shaded area the monthly mean \pm one standard deviation in the daily data. Vertical shaded areas indicate February in each year, when PSC are typically observed.

\section{References}

Bogdan, A., Molina, M. J., Kulmala, M., MacKenzie, A. R., and Laaksonen, A.: Study of finely divided aqueous systems as an aid to understanding the formation mechanism of polar stratospheric clouds: Case of $\mathrm{HNO}_{3} / \mathrm{H}_{2} \mathrm{O}$ and $\mathrm{H}_{2} \mathrm{SO}_{4} / \mathrm{H}_{2} \mathrm{O}$ systems, J. Geophys. Res.: Atmos., 108, 4302, 10.1029/2002JD002605, 2003.

Carrillo-Sánchez, J. D., Nesvorný, D., Pokorný, P., Janches, D., and Plane, J. M. C.: Sources of cosmic dust in the Earth's atmosphere, Geophys. Res. Lett., 43, 11,979911,986, 10.1002/2016GL071697, 2016.

English, J. M., Toon, O. B., Mills, M. J., and Yu, F.: Microphysical simulations of new particle formation in the upper troposphere and lower stratosphere, Atmospheric Chemistry and Physics, 11, 9303-9322, 10.5194/acp-11-9303-2011, 2011.

English, J. M., Toon, O. B., and Mills, M. J.: Microphysical simulations of sulfur burdens from stratospheric sulfur geoengineering, Atmos. Chem. Phys., 12, 47754793, 10.5194/acp-12-4775-2012, 2012. 
Feierabend, K. J., Havey, D. K., Brown, S. S., and Vaida, V.: Experimental absolute intensities of the $4 \mathrm{v}_{9}$ and $5 \mathrm{v}_{9} \mathrm{O}-\mathrm{H}$ stretching overtones of $\mathrm{H}_{2} \mathrm{SO}_{4}$, Chem. Phys. Lett., 420, 438-442, 10.1016/j.cplett.2006.01.013, 2006.

Hurrell, J. W., Holland, M. M., Gent, P. R., Ghan, S., Kay, J. E., Kushner, P. J., Lamarque, J. F., Large, W. G., Lawrence, D., Lindsay, K., Lipscomb, W. H., Long, M. C., Mahowald, N., Marsh, D. R., Neale, R. B., Rasch, P., Vavrus, S., Vertenstein, M., Bader, D., Collins, W. D., Hack, J. J., Kiehl, J., and Marshall, S.: The Community Earth System Model A Framework for Collaborative Research, Bull. Amer. Meteor. Soc., 94, 1339-1360, 10.1175/bams-d-12-00121.1, 2013.

Kalashnikova, O., Horanyi, M., Thomas, G. E., and Toon, O. B.: Meteoric smoke production in the atmosphere, Geophys. Res. Lett., 27, 3293-3296, 10.1029/1999gl011338, 2000.

Kinnison, D. E., Brasseur, G. P., Walters, S., Garcia, R. R., Marsh, D. R., Sassi, F., Harvey, V. L., Randall, C. E., Emmons, L., Lamarque, J. F., Hess, P., Orlando, J. J., Tie, X. X., Randel, W., Pan, L. L., Gettelman, A., Granier, C., Diehl, T., Niemeier, U., and Simmons, A. J.: Sensitivity of chemical tracers to meteorological parameters in the MOZART-3 chemical transport model, Journal of Geophysical Research: Atmospheres, 112, D20302, 10.1029/2006JD007879, 2007.

Lamarque, J. F., Emmons, L. K., Hess, P. G., Kinnison, D. E., Tilmes, S., Vitt, F., Heald, C. L., Holland, E. A., Lauritzen, P. H., Neu, J., Orlando, J. J., Rasch, P. J., and Tyndall, G. K.: CAM-chem: description and evaluation of interactive atmospheric chemistry in the Community Earth System Model, Geosci. Model Development, 5, 369-411, 10.5194/gmd-5-369-2012, 2012.

Lane, J. R., and Kjaergaard, H. G.: Calculated electronic transitions in sulfuric acid and implications for its photodissociation in the atmosphere, J. Phys. Chem. A, 112, 4958-4964, 10.1021/jp710863r, 2008.

Marsh, D. R., Mills, M. J., Kinnison, D. E., Lamarque, J. F., Calvo, N., and Polvani, L. M.: Climate Change from 1850 to 2005 Simulated in CESM1 (WACCM), J. Clim., 26, 7372-7391, 10.1175/jcli-d-12-00558.1, 2013.

Miller, Y., Gerber, R. B., and Vaida, V.: Photodissociation yields for vibrationally excited states of sulfuric acid under atmospheric conditions, Geophys. Res. Lett., 34, art. no.: L16820, 10.1029/2007gl030529, 2007.

Mills, M. J., Schmidt, A., Easter, R., Solomon, S., Kinnison, D. E., Ghan, S. J., Neely, R. R., Marsh, D. R., Conley, A., Bardeen, C. G., and Gettelman, A.: Global volcanic aerosol properties derived from emissions, 1990-2014, using CESM1 (WACCM), J. Geophys. Res., 121, 2332-2348, 10.1002/2015jd024290, 2016.

Rienecker, M. M., Suarez, M. J., Gelaro, R., Todling, R., Bacmeister, J., Liu, E., Bosilovich, M. G., Schubert, S. D., Takacs, L., Kim, G. K., Bloom, S., Chen, J. Y., Collins, D., Conaty, A., Da Silva, A., Gu, W., Joiner, J., Koster, R. D., Lucchesi, R., Molod, A., Owens, T., Pawson, S., Pegion, P., Redder, C. R., Reichle, R., Robertson, F. R., Ruddick, A. G., Sienkiewicz, M., and Woollen, J.: MERRA: NASA's Modern-Era Retrospective Analysis for Research and Applications, J. Clim., 24, 3624-3648, 10.1175/jcli-d-11-00015.1, 2011.

Saunders, R. W., Dhomse, S., Tian, W. S., Chipperfield, M. P., and Plane, J. M. C.: Interactions of meteoric smoke particles with sulphuric acid in the Earth's 
stratosphere, Atmos. Chem. Phys., 12, 4387-4398, 10.5194/acp-12-4387-2012, 2012.

Toon, O. B., Turco, R. P., Hamill, P., Kiang, C. S., and Whitten, R. C.: Onedimensional model describing aerosol formation and evolution in the stratosphere. 2. Sensitivity studies and comparison with observations, J. Atmos. Sci., 36, 718-736, 10.1175/1520-0469(1979)036<0718:aodmda>2.0.co;2, 1979.

Toon, O. B., Turco, R. P., Westphal, D., Malone, R., and Liu, M.: A Multidimensional Model for Aerosols: Description of Computational Analogs, J. Atmos. Sci., 45, 21232144, 10.1175/1520-0469(1988)045<2123:ammfad>2.0.co;2, 1988.

Turco, R. P., Hamill, P., Toon, O. B., Whitten, R. C., and Kiang, C. S.: Onedimensional model describing aerosol formation and evolution in the stratosphere. 1. Physical processes and mathematical analogs, J. Atmos. Sci., 36, 699-717, 10.1175/1520-0469(1979)036<0699:aodmda>2.0.co;2, 1979.

Voigt, C., Schlager, H., Luo, B. P., Dörnbrack, A., Roiger, A., Stock, P., Curtius, J., Vössing, H., Borrmann, S., Davies, S., Konopka, P., Schiller, C., Shur, G., and Peter, T.: Nitric Acid Trihydrate (NAT) formation at low NAT supersaturation in Polar Stratospheric Clouds (PSCs), Atmos. Chem. Phys., 5, 1371-1380, 10.5194/acp-51371-2005, 2005. 